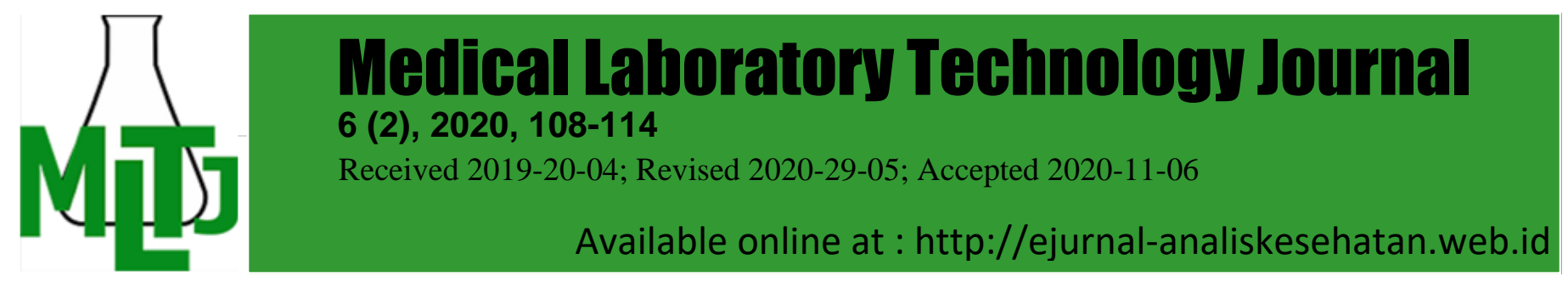

\title{
Stability of Routine Hematology Sample Using the Medonic M-Series Analyzer
}

\author{
*Eva Ayu Maharani, Dewi Astuti \\ Department of Medical Technology Laboratory Polytechnic of Health, Ministry of \\ Health, Jakarta III. Indonesia \\ *Email: evaayumaharani@gmail.com \\ DOI: $10.31964 / \mathrm{mltj} . v 0 \mathrm{i0} .305$
}

\begin{abstract}
Routine hematology tests $(\mathrm{Hb}, \mathrm{Hct}, \mathrm{RBC}, \mathrm{WBC}, \mathrm{PLT})$ generally done by automation methods using a hematology analyzer. Ideally, the examinations should be done as soon as possible, although, in some circumstances, it can be delayed. Based on the literature, the sample for routine hematology testing should be processed within $4-8$ hours of venesection. Some studies revealed that the sample could be stored for up to 48 hours, and it can be influenced by the technology applied to the hematology analyzer. Studies conducted to see the stability of the samples using a hematology analyzer with impedance technology. Tests performed on whole blood samples collected from 12 ostensibly healthy individuals, immediately after collection (fresh sample, <1hour) and $2 \mathrm{~h}, 4 \mathrm{~h}, 6 \mathrm{~h}, 8 \mathrm{~h}, 24 \mathrm{~h}, 48 \mathrm{~h}$ afterward. The samples stored at room temperature $\left(20-24^{\circ} \mathrm{C}\right)$ and $2-6^{\circ} \mathrm{C}$. There are no significant differences after $48 \mathrm{~h}$ under different storage conditions for $\mathrm{Hb}$, Hct, RBC, PLT count, except for WBC count that has a significant difference at temperature $2-6^{\circ} \mathrm{C}$. CV for $\mathrm{Hb}, \mathrm{Hct}, \mathrm{RBC}, \mathrm{PLT}, \mathrm{WBC}$ count is less than $5 \%$ at room temperature. WBC and PLT count have a CV of more than $5 \%$ at $2-6^{\circ} \mathrm{C}$. Sample for $\mathrm{Hb}, \mathrm{Hct}, \mathrm{RBC}$ was found to be stable up to $48 \mathrm{~h}$ at room temperature and $2-6^{\circ} \mathrm{C}$. PLT and WBC count were stable for $48 \mathrm{~h}$ if stored at room temperature.
\end{abstract}

Keyword: hematology analyzer; impedance; temperature

\section{INTRODUCTION}

Sample stability is one of the pre-analytical factors that have a very important role in determining the validity of laboratory test results. Ideally, routine hematology tests ( $\mathrm{Hb}, \mathrm{Hct}, \mathrm{RBC}, \mathrm{WBC}, \mathrm{PLT})$ should be done as soon as possible. In some circumstances, blood samples for routine hematology tests may be delayed because of the sample transportation to the referral laboratory. This causes the sample day's delay before analysis that could change and confound the interpretation of the results (Pintér et al., 2016). Laboratory technicians must understand sample stability to decide whether to accept or reject samples to get reliable results (Schapkaitz \& Pillay, 2015).

Based on the literature, the sample for routine hematology testing should be processed within $4-8$ hours of venipuncture. Recent studies have revealed that the stability of samples for routine hematology tests using a hematology analyzer has more extended stability for more than 8 hours (Tendulkar et al., 2015), and it can be influenced by the technology that applied to the hematology analyzer (Zini, 2014) (Jain Ashish et al., 2018). Sample storage in the refrigerator also can extend the stability of the blood cell count (Wood et al., 1999).

Most of the stability sample studies were used a hematology analyzer with flow cytometry technology, whereas the study with impedance technology is still 
limited. Stability studies conducted to determine the ability of the hematology analyzer to provide consistent results within the period and under certain conditions with a specific type of hematology analyzer.

This test can be performed to evaluate a hematology analyzer (Briggs et al., 2014). The purpose of this study is to determine the stability between fresh samples $(<1 \mathrm{~h})$ and stored samples $(2 \mathrm{~h}, 4 \mathrm{~h}, 6 \mathrm{~h}, 8 \mathrm{~h}, 24 \mathrm{~h}, 48 \mathrm{~h})$ at room temperature $\left(20-24^{\circ} \mathrm{C}\right)$ and $2-6^{\circ} \mathrm{C}$ using a hematology analyzer with impedance technology.

\section{MATERIALS AND METHOD}

Blood samples for routine hematology tests $(\mathrm{Hb}$, Hct, WBC, RBC, PLT) collected from 12 adults and ostensibly healthy volunteers recruited from the Health Polytechnic of Jakarta III staff. The Ethics Committee approved the study protocol of Health Polytechnic of Jakarta III with certificate number: KEPK-PKKJ3/200/V/2018. All volunteers provided written informed consent before the procedure.

Twelve samples were collected in $\mathrm{K}_{3}$ EDTA tubes and measured on a Medonic M-series (Medonic, 2016), within one h (fresh sample) and $2 \mathrm{~h}, 4 \mathrm{~h}, 6 \mathrm{~h}, 8 \mathrm{~h}$, $24 \mathrm{~h}, 48 \mathrm{~h}$ (stored samples) at room temperature $\left(20-24^{\circ} \mathrm{C}\right)$ and refrigerator $\left(2-6^{\circ} \mathrm{C}\right)$. Samples stored in the refrigerator were allowed to equilibrate at room temperature before measurement. Stability samples determined by comparing the results with statistical analysis (ANOVA test and coefficient of variation) at $2,4,6,8,24,48 \mathrm{~h}$ samples to $0 \mathrm{~h}$ (less than $1 \mathrm{~h} /$ fresh) samples.

The Medonic M-series used impedance technology for counting blood cells and spectrophotometry for $\mathrm{Hb}$ concentration measuring. The impedance technology measures changes in the electrical impedance produced by a cell passing through an aperture (Medonic, 2016).

ANOVA-test evaluated the difference between samples at various time points for normal distribution data, and abnormal distribution data used the Kruskal-Wallis test after verification of normal distribution by the Shapiro-Wilk test. Statistical significance was set for $p$-values $<0,05$. The coefficient of variation $(C V)$ between the fresh and stored samples was compared based on the CV values on the hematology analyzer.

\section{RESULTS AND DISCUSSION}

The mean values of test results $(\mathrm{Hb}, \mathrm{Hct}$ WBC, RBC, PLT) on a fresh sample and stored samples at room temperature shown in the range of normal values (Table 1). In stored samples at $2-6^{\circ} \mathrm{C}$ showed the mean values were in the range of normal values, except for WBC count at 48 hours of storage (Table 2).

Statistical analysis with ANOVA test conducted on the parameters with normal distribution data, which were $\mathrm{Hb}$, Hct, RBC, and PLT. The difference test for WBC count used the Kruskal-Wallis test because the data distribution was abnormal. The statistical difference test results showed no significant difference $(\alpha>$ 0.05 ) for $\mathrm{Hb}, \mathrm{Hct}, \mathrm{RBC}, \mathrm{WBC}$, and PLT after 48h of storage at room temperature.

The statistical difference test for samples stored at $2-6^{\circ} \mathrm{C}$ showed there were no significant differences $(\alpha>0.05)$, except for WBC count at $2-6^{\circ} \mathrm{C}$ (Table 3$)$. 
Table 1. The Mean Values \pm Standard Deviation (SD) of Routine Hematology Parameters in The Samples at Room Temperature $\left(20-24^{\circ} \mathrm{C}\right)$

\begin{tabular}{|c|c|c|c|c|c|c|c|}
\hline Ptored & $\begin{array}{l}\text { Immediately } \\
(<1 \mathrm{~h})\end{array}$ & $2 \mathrm{~h}$ & $4 \mathrm{~h}$ & $6 \mathrm{~h}$ & $8 \mathrm{~h}$ & $24 \mathrm{~h}$ & $48 \mathrm{~h}$ \\
\hline $\begin{array}{l}\mathrm{Hb}(\mathrm{g} / \\
\mathrm{dL})\end{array}$ & $13.2 \pm 1.5$ & $\begin{array}{c}13.4 \pm \\
1.6\end{array}$ & $\begin{array}{c}13.4 \pm \\
1.5\end{array}$ & $\begin{array}{c}13.4 \pm \\
1.5\end{array}$ & $\begin{array}{c}13.3 \pm \\
1.6\end{array}$ & $\begin{array}{c}13.3 \pm \\
1.6\end{array}$ & $\begin{array}{c}13.3 \pm \\
1.6\end{array}$ \\
\hline Hct (\%) & $37 \pm 4.8$ & $37 \pm 4.9$ & $37 \pm 4.8$ & $\begin{array}{c}37 \pm \\
4.8\end{array}$ & $37 \pm 5.2$ & $39 \pm 4.8$ & $\begin{array}{c}41 \pm \\
4.8\end{array}$ \\
\hline RBC & & & & & & & \\
\hline $\begin{array}{l}\text { count }(x \\
10^{6} \text { cells / } \\
\mathrm{mL}) \\
\text { WBC }\end{array}$ & $4.68 \pm 0.8$ & $\begin{array}{c}4.70 \pm \\
0.8\end{array}$ & $\begin{array}{c}4.71 \pm \\
0.8\end{array}$ & $\begin{array}{c}4.70 \pm \\
0.8\end{array}$ & $\begin{array}{c}4.68 \pm \\
0.8\end{array}$ & $\begin{array}{c}4.66 \pm \\
0.8\end{array}$ & $\begin{array}{c}4.68 \pm \\
0.8\end{array}$ \\
\hline $\begin{array}{l}\text { count }(x \\
10^{3} \text { cells / } \\
\mathrm{mL}) \\
\text { PLT }\end{array}$ & $6.6 \pm 1.9$ & $6.8 \pm 1.8$ & $\begin{array}{c}6.8 \pm \\
1.9\end{array}$ & $\begin{array}{c}6.8 \pm \\
1.8\end{array}$ & $\begin{array}{c}6.7 \pm \\
1.9\end{array}$ & $\begin{array}{c}6.5 \pm \\
1.9\end{array}$ & $\begin{array}{c}6.4 \pm \\
1.7\end{array}$ \\
\hline $\begin{array}{l}\text { count }(x \\
10^{3} \text { cells / } \\
\mathrm{mL})\end{array}$ & $275 \pm 59.8$ & $\begin{array}{c}283 \pm \\
58.9\end{array}$ & $\begin{array}{l}279 \pm \\
60.5\end{array}$ & $\begin{array}{l}277 \pm \\
63.2\end{array}$ & $\begin{array}{c}276 \pm \\
61.1\end{array}$ & $\begin{array}{c}272 \pm \\
62.2\end{array}$ & $\begin{array}{c}270 \pm \\
55.8\end{array}$ \\
\hline
\end{tabular}

Table 2. The Mean Values \pm Standard Deviation (SD) of Routine Hematology Parameters in The Samples at 2-6 ${ }^{0} \mathrm{C}$.

\begin{tabular}{|c|c|c|c|c|c|c|c|}
\hline Stored & $\begin{array}{l}\text { Immediately } \\
(<1 \text { hour })\end{array}$ & 2 hours & 4 hours & 6 hours & 8 hours & $\begin{array}{c}24 \\
\text { hours }\end{array}$ & $\begin{array}{c}48 \\
\text { hours }\end{array}$ \\
\hline $\mathrm{Hb}(\mathrm{g} / \mathrm{dL})$ & $13.2 \pm 1.5$ & $\begin{array}{c}13.4 \pm \\
1.6\end{array}$ & $\begin{array}{c}13.4 \pm \\
1.6\end{array}$ & $\begin{array}{c}13.3 \pm \\
1.6\end{array}$ & $\begin{array}{c}13.2 \pm \\
1.5\end{array}$ & $\begin{array}{c}13.2 \pm \\
1.6\end{array}$ & $\begin{array}{c}13.3 \pm \\
1.6\end{array}$ \\
\hline Hct (\%) & $37 \pm 4.8$ & $\begin{array}{c}37 \pm \\
4.8\end{array}$ & $37 \pm 5$ & $\begin{array}{c}37 \pm \\
4.9\end{array}$ & $\begin{array}{c}37 \pm \\
4.9\end{array}$ & $\begin{array}{c}37 \pm \\
4.8\end{array}$ & $\begin{array}{c}38 \pm \\
4.8\end{array}$ \\
\hline $\mathrm{RBC}$ & & & & & & & \\
\hline $\begin{array}{l}\text { count }(x \\
10^{6} \text { cells / } \\
\mathrm{mL}) \\
\text { WBC }\end{array}$ & $4.68 \pm 0.8$ & $\begin{array}{c}4.72 \pm \\
0.9\end{array}$ & $\begin{array}{c}4.69 \pm \\
0.9\end{array}$ & $\begin{array}{c}4.68 \pm \\
0.8\end{array}$ & $\begin{array}{c}4.64 \pm \\
0.8\end{array}$ & $\begin{array}{c}4.63 \pm \\
0.9\end{array}$ & $\begin{array}{c}4.66 \pm \\
0.8\end{array}$ \\
\hline $\begin{array}{l}\text { count ( } x \\
10^{3} \text { cells / } \\
\mathrm{mL})\end{array}$ & $6.6 \pm 1.9$ & $\begin{array}{c}6.8 \pm \\
1.8\end{array}$ & $\begin{array}{c}6.8 \pm \\
1.8\end{array}$ & $6.4 \pm 2$ & $\begin{array}{c}6.6 \pm \\
1.8\end{array}$ & $\begin{array}{c}6.4 \pm \\
1.6\end{array}$ & $\begin{array}{c}3.4 \pm \\
1.2\end{array}$ \\
\hline $\begin{array}{l}\text { PLT count } \\
\left(\times 10^{3} \text { cells }\right. \\
/ \mathrm{mL})\end{array}$ & $275 \pm 59.8$ & $\begin{array}{c}284 \pm \\
62.8\end{array}$ & $\begin{array}{c}281 \pm \\
57.1\end{array}$ & $\begin{array}{c}278 \pm \\
54.4\end{array}$ & $\begin{array}{c}281 \pm \\
57.3\end{array}$ & $\begin{array}{c}270 \pm \\
55.8\end{array}$ & $\begin{array}{c}244 \pm \\
56.1\end{array}$ \\
\hline
\end{tabular}


Table 3. Statistical Difference Test and \%CV of Routine Hematology Parameters

\begin{tabular}{|c|c|c|c|c|}
\hline \multirow[b]{2}{*}{ Parameter } & \multicolumn{2}{|c|}{ Significant Difference Test } & \multicolumn{2}{|c|}{$\begin{array}{c}\text { The Coefficient of Variation/ } \\
\text { CV (\%) }\end{array}$} \\
\hline & $\begin{array}{l}\mathrm{P} \text { values at } \\
\text { Room } \\
\text { Temperature }\end{array}$ & $\begin{array}{l}\mathrm{P} \text { values } \\
\text { at } 2-6^{\circ} \mathrm{C}\end{array}$ & $\begin{array}{c}\text { Room } \\
\text { Temperature }\end{array}$ & $2-6^{\circ} \mathrm{C}$ \\
\hline${ }^{*} \mathrm{Hb}(\mathrm{g} / \mathrm{dL})$ & 1,000 & 1.000 & 1.02 & 1.10 \\
\hline${ }^{*} \operatorname{Hct}(\%)$ &, 301 & .999 & 4.36 & 2.16 \\
\hline $\begin{array}{c}{ }^{*} \mathrm{RBC} \text { count }(\mathrm{X} \\
\left.10^{6} \text { cells } / \mu \mathrm{L}\right)\end{array}$ & 1,000 & 1,000 & .99 & 1.2 \\
\hline $\begin{array}{l}{ }^{*} \mathrm{PLT} \text { count }(\mathrm{X} \\
\left.10^{3} \text { cells } / \mu \mathrm{L}\right)\end{array}$ & 999 & 675 & 3.51 & 6.23 \\
\hline $\begin{array}{c}{ }^{*} \text { WBC count }(x \\
\left.10^{3} \text { cells } / \mu \mathrm{L}\right)\end{array}$ & 896 &, 000 & 3.21 & 19.95 \\
\hline
\end{tabular}

*Anova and **Kruskal Wallis test used for between-group differences. There were no significant difference if $p$ values $>0.05$.

The morphology of blood cells can change during storage and will affect the results of the examination (Antwi et al., 2013) (Choudhary et al., 2018). Several studies in the flow cytometry hematology analyzer show that blood samples can stable up to 48 hours. Another study with flow cytometry technology, also obtained similar results, except for Hct value that only stable up to 8 hours (Daves et al., 2015) (Buoro et al., 2016). Different study analyzer with flow cytometry reveals that Hct was stable at room temperature until 48 hours and 168 hours when stored at 4$8^{0} \mathrm{C}$ (Schapkaitz \& Pillay, 2015). Those studies show that each of the hematology analyzers has its characteristics to the stability of the samples. In this study, we use impedance technology because we still have limited knowledge of sample stability on its technology. One of the studies with impedance technology showed that most of the parameters (WBC, RBC, HB, Hct, MCV, MCH, PLT) stable for at least 24 hours at $4^{\circ} \mathrm{C}$, while there is an unacceptable bias of Hct and MCV after 12 hours at $22^{\circ} \mathrm{C}$ (Ashish et al., 2017).

The coefficient of variation (CV) for each parameter in this study, showed quite a wide variation, especially for sample WBC count stored at $2-6^{0} \mathrm{C}$ (Table 3 ). The smallest variation was the RBC count parameter from the sample stored at room temperature. WBC count is known to have the highest CV (19.95\%) on $48 \mathrm{~h}$ stored samples at $2-6^{\circ} \mathrm{C}$ temperatures. The higher $\mathrm{CV}$ values mean the result imprecision. Ideally, the value of the CV in hematology parameters should be less than $5 \%$, and more precise in the hematology analyzer, as these instruments have a high level of precision (WHO et al., 2011) (WHO, n.d.). Interpretation of CV value and the different statistical analyses in WBC count at $2-6^{\circ} \mathrm{C}$ have the same meaning that showed the sample have a bad precision on 48 hours storage. This can cause the morphological changes in leukocytes at a storage temperature of $2-8^{\circ} \mathrm{C}$ that began to happen in the storage period of 48 hours (Rahmnitarini et al., 2019).

The cells are swelling, which can cause misinterpretation in counting leukocytes, especially in impedance technology. Impedance technology in the hematology analyzer measures cell volume for all cell types (Chhabra, 2018). This study also showed that the WBC count using stored samples in $2-6^{\circ} \mathrm{C}$ has a big difference that can make a different interpretation of the results based on the normal value. 
On the contrary, the PLT count has different interpretations between the two analyses. There is no significant difference in PLT count (Table 3), but the sample stored 48 hours at room temperature showed poor precision because of the $\mathrm{CV}$ values more than $5 \%$. Prior studies on platelet counts have proved that sample storage affects the platelet volume and causes clumping in EDTA blood, which in turn is responsible for the low platelet values, and make a variation between different storage sample (Tendulkar et al., 2015) (Fang et al., 2015). This study also shows that a sample stored at $2-6^{\circ} \mathrm{C}$ has a larger $\mathrm{CV}$ value than the sample stored at room temperature.

In the $\mathrm{Hb}$ parameter, the sample stored at room temperature or $2-6^{\circ} \mathrm{C}$ still provides excellent results for up to 48 hours of storage and an erythrocyte count. Our results correlated with (Mahadeo et al., 2014) and (Tendulkar et al., 2015). Although in some studies, $\mathrm{Hb}$ and erythrocyte count, less stable at $4^{\circ} \mathrm{C}$, which may be affected by initial freezing followed by refrigeration (Wu et al., 2017). The result with high variation can give a different interpretation. For example, the fresh sample has a result on normal range values, but after stored in a few hours, the results can be outside the normal value. This showed that change in each result of the hematology routine was linear with time and temperature, as delay in testing can lead to changes in blood components (Mahadeo et al., 2014). The difference results among other studies may be due to different experimental conditions and analyzer types (Hussain, 2019).

The limitations of this study, the sample is measured within 48 hours as the maximum storage time, so the maximum stability of the sample after 48 hours for the $\mathrm{Hb}$, Hct, and RBC parameters is not yet known.

\section{CONCLUSION}

The stored samples for the parameter of $\mathrm{Hb}$, Hct, and $\mathrm{RBC}$ have excellent stability and precision until $48 \mathrm{~h}$, stored at room temperature $\left(22 \pm 2^{\circ} \mathrm{C}\right)$ and $2-6^{\circ} \mathrm{C}$, while PLT and WBC count has a poor precision for $48 \mathrm{~h}$ samples stored at $2-6^{\circ} \mathrm{C}$. Therefore, it recommended keeping the sample for routine hematology test using Medonic M-series, at room temperature $\left(22 \pm 2^{\circ} \mathrm{C}\right)$, with confirmation examination not more than 24 hours, except for WBC count, that should analyze within 2 hours.

\section{ACKNOWLEDGEMENT}

MRK Diagnostic partially supported this research. We thank Mr. Ruben Schnapke as general manager of MRK Diagnostics and Mr. Suprayogi as an application supervisor for supporting materials used in this research.

\section{CONFLICT OF INTEREST}

There is no conflict of interest with other parties in this research.

\section{REFERENCE}

Antwi, B. S., Elizabeth, Q., Ransford, K., \& Abdulai, M. S. (2013). Prolong Storage of Blood in EDTA Has an Effect on the Morphology and Osmotic Fragility of Erythrocytes. International Journal of Biomedical Science and Engineering, 1(2), 20. https://doi.org/10.11648/j.ijbse.20130102.11

Ashish, J., Sanchit, J., Neha, S., Priyanka, A., Shweta, P., Sushant, M. K., \& Nilotpal, C. (2017). Stability of Commonly Used Hematological Parameters in Samples Stored at $33^{\circ} \mathrm{C}, \quad 22^{\circ} \mathrm{C}$ and $4^{\circ} \mathrm{C}$. BiorXiv. https://doi.org/https://doi.org/10.1101/148601 
Briggs, C., Culp, N., Davis, B., d'Onofrio, G., Zini, G., \& Machin, S. J. (2014). ICSH guidelines for the evaluation of blood cell analysers including those used for differential leucocyte and reticulocyte counting. International Journal of Laboratory Hematology, 36(6), 613-627. https://doi.org/10.1111/ijlh.12201

Buoro, S., Mecca, T., Seghezzi, M., Manenti, B., Cerutti, L., Dominoni, P., Napolitano, G., Resmini, S., Crippa, A., Ottomano, C., \& Lippi, G. (2016). Assessment of blood sample stability for complete blood count using the Sysmex XN-9000 and Mindray BC-6800 analyzers. Revista Brasileira de Hematologia e Hemoterapia, 38(3), 225-239. https://doi.org/10.1016/j.bjhh.2016.05.010

Chhabra, G. (2018). Automated Hematology Analyzers: Recent Trends and Applications. Journal of Laboratory Physicians, 10(15-16). https://www.ncbi.nlm.nih.gov/pmc/articles/PMC5784285/

Choudhary, S., Katkar, R. S., \& Nagaram, D. (2018). Storage artifacts in peripheral blood smears. IP Journal of Diagnostic Pathology and Oncology, 3(3), 187191. https://doi.org/10.18231/2581-3706.2018.0039

Daves, M., Zagler, E. M., Cemin, R., Gnech, F., Joos, A., Platzgummer, S., \& Lippi, G. (2015). Sample stability for complete blood cell count using the Sysmex XN hematological analyzer. Blood Transfusion, 13(4), 576-582. https://doi.org/10.2450/2015.0007-15

Fang, C. H., Chien, Y. L., Yang, L. M., Lu, W. J., \& Lin, M. F. (2015). EDTAdependent pseudo thrombocytopenia. Formosan Journal of Surgery, 48(3), 107-109. https://doi.org/10.1016/j.fjs.2015.01.003

Hussain, S. (2019). Stability and Reliability of Complete Blood Count Parameters with Extended Storage toward Pathological Applications with Defined Specifications : A Mini. Oncol Clin Res (ONCR), 1(1), 18-21.

Jain, A., Sanchit, J., Neha, S., Priyanka, A., Shweta, P., Sushant, M. K., \& Nilotpal, C. (2018). Storage stability of commonly used hematological parameters at $330 \quad$ C. Biochem Med, 28(2), https://doi.org/https://doi.org/10.11613/BM.2018.020901

Mahadeo, M., CM, K., Mohana, L. T., \& Prabhakar, R. E. (2014). Storage And Stability Of Blood Samples - Changes In The Haematological Values. Journal Pharmaceutical and Biomedical Sciences, 4(8), 685-687.

Medonic. (2016). Medonic M-Series User's Manual. Boule Medical AB.

Pintér, E., László, K., Schüszler, I., \& Konderák, J. (2016). The stability of quantitative blood count parameters using the ADVIA 2120i hematology analyzer. Practical Laboratory Medicine, 4(2016), 16-21. https://doi.org/10.1016/j.plabm.2015.12.001

Rahmnitarini, A., Hernaningsih, Y., \& Indrasari, Y. N. (2019). The stability of sample storage for complete blood count ( CBC ) toward the blood cell morphology. Bali Medical Journal, 8(2), 391-395. https://doi.org/10.15562/bmj.v8i2.1369

Schapkaitz, E., \& Pillay, D. (2015). Prolonged storage-induced changes in hematology parameters referred for testing. African Journal of Laboratory Medicine, 4(1), 1-8. https://doi.org/10.4102/ajlm.v4i1.208

Tendulkar, A., Jain, P., Gujral, S., Tambe, M., Kenjale, R., \& Ganesh, B. (2015). Stability of Selected Hematological Parameters in Stored Blood Samples. Journal of Cell Science \& Therapy, 6(5). https://doi.org/10.4172/21577013.1000220

WHO. (n.d.). WHO_LAB_98.4.pdf. 
WHO, CDC, \& CLSI. (2011). Quality Management System Handbook. In the Laboratory quality management system: a handbook. https://doi.org/10.1007/s11130-014-0442-9

Wood, B. L., Andrews, J., Miller, S., \& Sabath, D. E. (1999). Refrigerated storage improves the stability of the complete blood cell count and automated differential. American Journal of Clinical Pathology, 112(5), 687-695. https://doi.org/10.1093/ajcp/112.5.687

Wu, D., Li, Y., \& Wang, F. (2017). EBioMedicine How Long can we Store Blood Samples: A Systematic Review and Meta-Analysis. EBioMedicine, 24, 277285. https://doi.org/10.1016/j.ebiom.2017.09.024

Zini, G. (2014). Stability of complete blood count parameters with storage: Toward defined specifications for different diagnostic applications. International Journal of Laboratory Hematology, 36(2), 111-113. https://doi.org/10.1111/ijlh.12181 